\title{
THE LANDSCAPING FEATURES OF THE CITY OF BALASHOV, RUSSIA
}

\author{
Ekaterina Alexandrovna Vetrova ${ }^{1 *}$, Elena Evgen'evna Kabanova ${ }^{2}$, Elena Vladimirovna Dupliy ${ }^{3}$, \\ Julia Olegovna Sulyagina ${ }^{3}$, Sergey Anatolyevich Makushkin ${ }^{3}$ \\ ${ }^{1 *}$ Moscow State University of Food Production, Department of Business Management \\ and Service Technologies, Moscow, Russian Federation; \\ ${ }^{2}$ Moscow State University of Food Production, Department of Business Management \\ and Service Technologies, Moscow, Russian Federation; \\ ${ }^{3}$ Russian State Social University, Wilhelm Pieck Street, 4-1, Moscow, 129226, Russian Federation; \\ *Corresponding Author Ekaterina Alexandrovna Vetrova, e-mail: ekaterina.a.vetrova@ mail.ru;
}

Received November 2021; Accepted December 2021; Published January 2022;

DOI: https://doi.org/10.31407/ijees12.116

\begin{abstract}
The landscaping of any urban, municipal, or rural district or settlement is one of the most important indicators in the modern world. The relevance of this topic is growing every year, due to the constant growth and development of the industrial activity of cities, as well as increasing settlement of territories by people. This problem is particularly acute in developed countries, so it is the subject of special attention of all authorities, various political parties, the media, and the general population. People, within their capacity, strive to improve their personal space, while wishing that the surrounding territories, namely the territories of "common use", were of a decent level, because this contributes to creating conditions for a comfortable life not only for an individual but also for the entire population living in a certain city, settlement, district, or micro district. The problem of landscaping is extremely relevant for a long time. The level of landscaping in almost all cities, settlements, and districts does not reach the necessary level for a comfortable life of society. Since the territories of "common use" do not meet the continuously increasing criteria of a modern person's life. Therefore, only a small part of Russian citizens are satisfied with the state of landscaping.
\end{abstract}

Keywords: landscaping, local self-government, municipal formation, urban space, housing, and communal services. 